\title{
Evaluation of Inhibitory Zone Diameter (IZD), Phytochemical Screening, Elemental Composition and Proximate Analysis of Crude Cleistopholis Patens (Benth) on Infectious Clinical Isolates
}

\author{
Oludare Temitope Osuntokun* \\ Department of Microbiology, Adekunle Ajasin University, Ondo State, Nigeria
}

\begin{abstract}
This purpose of this study is to determine the Inhibitory zone diameter (Izd), phytochemical screening, elemental composition and proximate analysis of crude Cleistopholis patens leaf, bark, aqueous and ethanol extracts on selected pathogenic isolates. The leaf and bark of Cleistopholis patens plants were obtained from a location in the southwestern part of Nigeria, in the tropical rainforest of Ikare Akoko, Ondo state and Ile Ife, Osun state, Nigeria. The six (6) bacterial isolates include Escherichia coli, Salmonella typhi, Candida albicans, Klebsiella pneumonia, Aspergilus flavus, and Staphylococcus aureus. Bacteria isolate were identified by various biochemical tests and morphological characteristics. Four concentrations were used to determine the Inhibitory zone Diameter namely; $60,30,15$, and $7.5 \mathrm{mg} / \mathrm{ml}$ and two controls were used namely; Ciprofloxacin and Metronidazole. All clinical organisms show higher zones of inhibition at $60 \mathrm{mg} / \mathrm{ml}$ and lower zones of inhibition at $7.5 \mathrm{mg} / \mathrm{ml}$ while control shows 28.0 at $30 \mathrm{mg} / \mathrm{ml}$ zones of inhibition on Klebsiella pneumoniae, while Salmonella typhi and Aspergilius flavus shows lower zone of inhibition at $30 \mathrm{mg} / \mathrm{ml}$. In qualitative phytochemical screening of Cleistopholis patens stem bark extract, it was observed that alkaloid and anthraquinone are negative while cardiac glycoside, steroid, phenol, tannins, saponin, and flavonoids were positive. in qualitative phytochemical screening of Cleistopholis patens Leaf extract, alkaloid, steroid, and anthraquinone are negative while cardiac glycoside, phenol, tannins, saponin and flavonoids are positive. In the elemental determination of Cleistopholis patens stem bark extract Zinc ( $\mathrm{Zn}$ ) has 28.0 $\mathrm{mg} / \mathrm{g}$ which is the highest value while copper has the lowest value which is $0.03 \mathrm{mg} / \mathrm{g}$. In Cleistopholis patens leaf extract, Calcium (Ca) has $25.32 \mathrm{mg} / \mathrm{g}$ which is the highest while copper has the lowest which is $0.03 \mathrm{mg} / \mathrm{g}$. while Lead $(\mathrm{Pb})$ was not detected. In Cleistopholis patens stem bark extract (Phylate) has the highest anti-nutrients which is $17.30 \%$ while Alkaloids has the lowest anti-nutrients which are $1.23 \%$. In Cleistopholis patens leaf extract Phylate, has the highest anti-nutrients, value $17.27 \%$ while Alkaloids has the lowest anti-nutrients value, $1.25 \%$. In Cleistopholis patens stem bark extract, carbohydrate has the highest percentage which is $46.69 \%$ and fat has the lowest percentage which is $6.48 \%$. In Cleistopholis patens leaf extract, carbohydrate has the highest percentage which is $48.91 \%$ and fat has the lowest percentage which is $8.53 \%$. Cleistopholis patens is useful for the treatment of infectious diseases.
\end{abstract}

Keywords: Inhibitory zone diameter (IZD); Phytochemical screening; Elemental composition; Proximate analysis; Crude Cleistopholis patens (Benth)

\section{Introduction}

Medicinal plants are widely used in management of diseases all over the world $[1,2]$. Historically, the use of medicinal plants is as old as mankind and medicine. In Nigeria, several thousands of plant species have been claimed to possess medicinal properties and employed in the treatment of many ailments [3].

Cleistopholis patens (Benth) Engl. and Diels found distributed in various parts of tropical Africa, in the rain forest region such as Burkina Faso, Cote d' ivoire, Ghana, Liberia, Sierra Leone, Togo and Nigeria. Cleistopholis patens (Benth) is a tree $20-30 \mathrm{~m}$ tall, with a trunk up to $10 \mathrm{~m}$ tall and $20-90 \mathrm{~cm}$ wide, its back is grayish-white, smooth fibrous or furrowed. It is a fast growing, commonly seen in forests and rapidly colonizing abandoned areas. The bole is slender, cylindrical and straight and its timber is straight grained. The tree is sun-loving, common in distributed forest and rapidly colonizing abandoned areas. It is used in traditional medical practices in many parts of Africa where it has several applications [4].

Cleistopholis patens (Benth) are potent anti-fungal agents effective against Klebsiella pneumonia [5] Cleistopholis patens are widely distributed from Senegal eastward to Uganda, and southward to DR Congo and Cabinda (Angola). Cleistopholis patens is most commonly found in riverine and swamp forest, and in secondary forest. It prefers flat, disturbed and wet sites, but can also be found in evergreen forest on slopes, up to $1100 \mathrm{~m}$ altitude. It does not tolerate fire. The wood is only used locally and not or rarely traded on the international market.

Cleistopholis patens and related species will remain of local importance as producer of wood that is easy to work. Its invasive nature in disturbed forest and rapid growth seem to offer good possibilities for commercial timber production on suitable sites in evergreen lowland forest, especially for veneer, plywood and particle board production. Several of the applications in traditional medicine have been confirmed by research, e.g. antimicrobial, anthelmintic and antimalarial activities. This may offer opportunities for drug development [6].

*Corresponding author: Oludare Temitope Osuntokun, Department of Microbiology, Adekunle Ajasin University, Akungba Akoko, P.M.B 001, Ondo State, Nigeria; Tel: +234 705789 0597; E-mail: osuntokun4m@yahoo.com

Received February 18, 2018; Accepted February 26, 2018; Published February 28, 2018

Citation: Osuntokun OT (2018) Evaluation of Inhibitory Zone Diameter (IZD), Phytochemical Screening, Elemental Composition and Proximate Analysis of Crude Cleistopholis Patens (Benth) on Infectious Clinical Isolates. J Mol Biomark Diagn 9: 385. doi: 10.4172/2155-9929.1000385

Copyright: ( 2018 Osuntokun OT. This is an open-access article distributed under the terms of the Creative Commons Attribution License, which permits unrestricted use, distribution, and reproduction in any medium, provided the original author and source are credited. 
Cleistopholis patens have exhibited significant activity against Candida albicans, Aspergillus fumigatus, and Cryptococcus neoformans was isolated from the root bark of Cleistopholis patens [5]. The antiplasmodial activity of nonvolatile and volatile extract from the stem bark of Cleistopholis patens had been reported [7]. According to ethno medicinal report the stem bark of the plant is used in the treatment of jaundice, infective hepatitis and stomach disorders. The roots are used as a vermifurge and the leaves are said to remedy fever.

\section{Materials and Methods}

\section{Plant collection/source}

The leaf and bark of the selected plants were obtained from a location in the southwestern part of Nigeria, in the tropical rainforest of Ikare Akoko, Ondo state and Ile Ife, Osun state, Nigeria. The plant were authenticated by a certified botanist at the herbarium unit of Department of Plant science and Biotechnology, Adekunle Ajasin University, Akungba Akoko, Ondo State, Nigeria and Obafemi Awolowo University, Ile Ife, Osun state, Nigeria. The leaves and stem bark was washed thoroughly with distilled water, stored in air tight containers and kept at room temperature prior to use [8].

\section{Test organisms}

The test organisms used in this study were Salmonella typhi, Klebsiella pneumoniae, Escherichia coli and Candida albican. Staphylococcus aureus and Aspergillus flavus. They were obtained from the Adekunle Ajasin University, Akungba Akoko, Ondo State, Nigeria and Obafemi Awolowo University, Ile Ife, Osun state, Nigeria They were isolated on sterile nutrient agar slants and taken to the microbiology laboratory of the Adekunle Ajasin University, Akungba Akoko, Nigeria. All slants of test organisms were kept at $-4^{\circ} \mathrm{C}$ prior to bioassay of the extracts. Extensive biochemical tests were carried out to further confirm all the test bacterial strains [9].

\section{Preparation of plant extracts for extraction}

All the plant materials obtained were first washed thoroughly with sterile distilled water and air dried at room temperature for about two weeks to ensure that the samples lose most of their moisture content. The following extractions were carried out: aqueous and Ethanol. For each extraction, $250 \mathrm{~g}$ of each dried plant material was weighed separately into conical flasks containing $750 \mathrm{ml}$ each of distilled water and ethanol. The mixtures were initially shaken rigorously and left for 9 days. All mixtures were filtered using sterile Whatman filter papers and the filtrates were collected directly into sterile crucibles. All filtrates obtained were introduced into sterile reaction tubes and heated continuously in water bath at the following temperatures: $78^{\circ} \mathrm{C}$ for ethanol extraction and $105^{\circ} \mathrm{C}$ for distilled water. The residues obtained were kept at room temperature [10].

\section{Standardization of extracts}

Using aseptic condition, the extract is reconstituted by adding 1.2 $\mathrm{g}$ of each extract with $5 \mathrm{ml}$ of dimethylsulphoxide (DMSO) and $15 \mathrm{ml}$ of sterile distilled water making it $60 \mathrm{mg} / \mathrm{ml}$. For each extract $7.5 \mathrm{ml}$ of distilled water is measured into three sterile bijou bottles. In bijou bottle A $7.5 \mathrm{ml}$ from $60 \mathrm{mg} / \mathrm{ml}$ extract was added and in bijou bottle B $2.5 \mathrm{ml}$ from $60 \mathrm{mg} / \mathrm{ml}$ extract was added and bijou bottle C $2.5 \mathrm{ml}$ from bijou bottle A was added. A is $30 \mathrm{mg} / \mathrm{ml}$, B is $15 \mathrm{mg} / \mathrm{ml}, \mathrm{C}$ is $7.5 \mathrm{mg} / \mathrm{ml}$ respectively [11].

\section{Standardization of inoculum}

Slants of the various organisms were reconstituted using an aseptic condition. Using a sterile wire loop, approximately one isolated colony of each pure culture was transferred into $5 \mathrm{ml}$ of sterile nutrient broth and incubated for 24 hours. After incubation, transfer $0.1 \mathrm{ml}$ of the isolated colony using a sterile needle and syringe into $9.9 \mathrm{ml}$ of sterile distilled water contained in each test tube and then mixed properly. The liquid now serves as a source of inoculum containing approximately $10^{6} \mathrm{cfu} / \mathrm{ml}$ of bacterial suspension [12].

\section{Antimicrobial assay of Cleistopholis patens (Benth) extracts using agar well diffusion method}

All antibacterial assays for the plant extracts were carried out by well diffusion technique. All the test organisms were sub-cultured onto sterile Mueller Hinton Agar plates and incubated at $37^{\circ} \mathrm{C}$ for 18 $24 \mathrm{~h}$. Five distinct colonies for each organism were inoculated onto sterile Mueller Hinton broth and incubated for 3-4 h. All innocula was standardized accordingly to match the $0.5 \mathrm{McF}$ arland standards and this standard was used for all susceptibility tests. All the extracts were reconstituted accordingly into the following concentrations: 60, 30, 15 and $7.5 \mathrm{mg} / \mathrm{ml}$; using the Dimethyl Sulphoxide (DMSO). The susceptibility testing was investigated by the Agar well diffusion method. A $0.1 \mathrm{ml}$ of $1: 10,000$ dilutions (equivalent to $10^{6} \mathrm{cfu} / \mathrm{mL}$ ) of fresh overnight culture of the clinical isolates grown in Muller Hinton agar and potato dextrose agar was seeded into $40 \mathrm{~mL}$ of Muller Hinton agar, and properly mixed in universal bottles. The mixture was aseptically poured into sterile Petri dishes and allowed to set. Using a sterile cork borer of $4 \mathrm{~mm}$ diameter, equidistant wells were made in the agar. Drops of the re-suspended, $(2 \mathrm{~mL}$ per well $)$ extracts with concentrations between 60 to $7.5 \mathrm{mg} / \mathrm{mL}$ were introduced into the wells till it was filled. Ciprofloxacin and Metronidazole $2 \mathrm{mg} / \mathrm{mL}$ were used as the control experiment. The plates were allowed to stand on the bench for an hour, to allow pre-diffusion of the extracts before incubation at $37^{\circ} \mathrm{C}$ for 24 hours. The zones of inhibition were measured to the nearest millimeter $(\mathrm{mm})$ using a standard transparent meter rule. All experiments were performed in duplicates $[10,11,13]$.

\section{Phytochemical screening of Cleistopholis patens (Benth) (qualitative method of analyses)}

Phytochemical screening of Cleistopholis patens extracts was carried out using the method of Trease and Evans and Sofowara [14,15].

Test for alkaloids: Acidic solution of the crude extract was prepared by dissolving $50 \mathrm{mg}$ of the extract in $10 \mathrm{ml}$ of $10 \%(\mathrm{v} / \mathrm{v}) \mathrm{HCI}$, heated and filtered. To $1.0 \mathrm{ml}$ of the filtrate in separate test tubes was added $1.0 \mathrm{ml}$ of Mayer's reagent. Formation of reddish brown precipitate indicated presence of alkaloids (positive result).

Test for tannins (ferric chloride reagent test): The Cleistopholis patens extract $(0.05 \mathrm{~g})$ was dissolved in $20 \mathrm{ml}$ of distilled water in separate test tubes and filtered. To the test tube, $1.0 \mathrm{ml}$ of the filtrate was added few drops (2-3) of $0.1 \%$ ferric chloride $\left(\mathrm{FeC1}_{3}\right)$ in glacial acetic acid solution. The mixture was examined for the formation of blue, brownish green or blue-black precipitate $[16,17]$.

Test for saponins (Frothing test): The Cleistopholis patens extract $(0.1$ g) was suspended in water in a test tube, shaken vigorously and checked for froth. It was warmed gently at $50^{\circ} \mathrm{C}$ for 10 minutes in water bath apparatus and shaken vigorously again. Frothing which persisted on warming was a preliminary evidence of the presence of saponins [14].

Test for anthraquinones: One milliliter $(1 \mathrm{ml})$ of the Cleistopholis patens filtrate was shaken with $10 \mathrm{ml}$ of benzene; the mixture was filtered and $5 \mathrm{ml}$ of $10 \%(\mathrm{v} / \mathrm{v})$ ammonia was added, then shaken and observed. A pinkish solution indicated a positive test [16]. 
Test for flavonoids: The Cleistopholis patens extract $(0.05 \mathrm{~g})$ was dissolved in $4 \mathrm{ml}$ of distilled water and filtered. To $1.0 \mathrm{ml}$ of the filtrate, few drops (2-3) of ethanolic potassium hydroxide solution were added. The formation of suspension, cloudiness or precipitate was taken as the evidence presence of flavonoids $[14,16]$.

Test for free reducing sugar (Fehling's test): One milliliter of the Cleistopholis patens filtrate was mixed with Fehling A and Fehling B separately; a brown colour with Fehling B and a green colour with Fehling A indicate the presence of reducing sugars [14].

Test for cyanogenic glucosides: $\mathrm{To} 10 \mathrm{ml}$ of $50 \% \mathrm{H}_{2} \mathrm{SO}_{4}$ was added to $1 \mathrm{ml}$ of Cleistopholis patens extract in a boiling tube. The mixture was heated in boiling water for 5 minutes. Then $10 \mathrm{ml}$ of Fehling's solution ( $5 \mathrm{ml}$ of each solution A and B) was added and boiled. A brick red precipitate indicated the presence of glycosides [14].

Test for cardiac glycosides (Keller-Killiani test): To $0.5 \mathrm{~g}$ of the Cleistopholis patens extract diluted in $5 \mathrm{ml}$ of water, $2 \mathrm{ml}$ of glacial acetic acid containing one drop of ferric chloride solution was added. This was underlayed with $1 \mathrm{ml}$ of concentrated sulphuric acid. A brown ring at the interface indicated the presence of a deoxy sugar characteristic of cardenolides, while in the acetic acid layer, a greenish ring formed just above the brown ring and gradually spread throughout this layer [18].

Test for steroids (Salkowaski reaction): A few milligram of the Cleistopholis patens extract was dissolved in $2 \mathrm{ml}$ chloroform and then $2 \mathrm{ml}$ of conc. $\mathrm{H}_{2} \mathrm{SO}_{4}$ was added from the sides of the test tube. The test tube was shaken for a few minutes. Red colour development in the chloroform layer indicated the presence of sterols [19]

\section{Quantitative phytochemical analyses of cleistopholis patens extracts (root, leaf, and stem bark)}

Estimation of saponins: About 20 grams each of dried plant samples were ground and, put into a conical flask after which $100 \mathrm{ml}$ of $20 \%$ aqueous and ethanol were added. The mixture was heated using a hot water bath at $55^{\circ} \mathrm{C}$, for 4 hours with continuous stirring, after which the mixture was filtered, and the residue re-extracted further with a $200 \mathrm{ml}$ of $20 \%$ ethanol. The combined extracts were reduced to $40 \mathrm{ml}$ over a water bath at $90^{\circ} \mathrm{C}$. The concentrate was transferred into a $250 \mathrm{ml}$ separatory funnel and $20 \mathrm{ml}$ of diethyl ether was added and then shaken vigorously. The aqueous layer was recovered while the ether layer was discarded. The purification process was repeated three times. Then $60 \mathrm{ml}$ of $\mathrm{n}$-butanol was added. The combined n-butanol extracts were washed twice with $10 \mathrm{~m} 1$ of $5 \%$ aqueous sodium chloride. The remaining solution was heated in a water bath. After evaporation, the samples were dried in the oven to a constant weight; the saponin content was calculated as percentage of the starting material [16].

Estimation of total flavonoid concentration: The concentration of flavonoids in the extract was estimated spectrophotometrically according to the procedure of Sun et al. [20]. The extract $(0.1 \mathrm{~g})$ was dissolved in $20 \mathrm{ml}$ of $70 \%(\mathrm{v} / \mathrm{v})$ ethanol to give a final concentration of $0.5 \mathrm{mg} / \mathrm{ml}$. To clean dry test tubes (in triplicate) were pipetted $0.5 \mathrm{ml}$ of working solution of sample and diluted with $4.5 \mathrm{ml}$ distilled water. To each test tube was added $0.3 \mathrm{ml}$ of $5 \%(\mathrm{w} / \mathrm{v}) \mathrm{NaNO}_{2}, 0.3 \mathrm{ml}$ of $10 \% \mathrm{Aid}_{3}$ and $4 \mathrm{ml}$ of $4 \%(\mathrm{w} / \mathrm{v}) \mathrm{NaOH}$. The reaction mixtures were incubated at room temperature for 15 minutes. The absorbance was read at 500 $\mathrm{nm}$ against reagent blank. The standard calibration curve was prepared by pipetting $0.2,0.4,0.6,0.8,1.0 \mathrm{ml}$ of $1 \mathrm{mg} / \mathrm{ml}$ rutin into clean dry test tubes. The volumes were made up to $5 \mathrm{ml}$ with distilled water. To each of the tubes were added $0.3 \mathrm{ml}$ of $5 \%(\mathrm{w} / \mathrm{v}) \mathrm{NaNO}_{2}, 0.3 \mathrm{ml}$ of $5 \%(\mathrm{w} / \mathrm{v}) \mathrm{Aid}_{3}$ and $4 \mathrm{ml}$ of $4 \%(\mathrm{w} / \mathrm{v}) \mathrm{NaOH}$. The reaction mixture was incubated at room temperature for $15 \mathrm{~min}$. Absorbance was taken at $500 \mathrm{~nm}$ and was plotted against the concentration to give the standard calibration curve. The concentrations of the flavonoids in the extract was extrapolated from standard calibration curve and expressed as milligram rutin equivalent per $\mathrm{g}$ of extract (mg RE/g extract) [16].

Estimation of cardiac glucosides (Borntrager's Test): To $2 \mathrm{ml}$ of filtrate hydrolysate, $3 \mathrm{ml}$ of ethyl acetate was added and shaken, ethyl acetate layer was separated and $10 \%$ ammonia solution were added to it. Formation of pink color indicated the presence of anthroquinone glycosides.

Detection of alkaloid content: Five grams of the plant sample was weighed into a $250 \mathrm{ml}$ beaker and $200 \mathrm{ml}$ of $10 \%$ acetic acid in ethanol was then added. The reaction mixture was covered and allowed to stand for 4 hour. This was filtered and the extract was concentrated on a water bath to one-quarter of the original volume. Concentrated ammonium hydroxide was added drop-wise to the extract until the precipitation was completed. The whole solution was allowed to settle and the precipitate was collected, washed with dilute ammonium hydroxide and then filtered; the residue being the alkaloid was dried and weighed to a constant mass [16].

Estimation of phlobatannins: About 0.5 grams of each Cleistopholis patens extracts was dissolved in distilled water and filtered. The filtrates were boiled in $2 \% \mathrm{HCl}$, Red precipitate showed the presence of phlobatannins.

Estimation of total phenolic concentration: Estimation of total phenolic content was carried out using Folin-Ciocalteu's phenol reagent reaction as reported by Singleton et al. [21]. The assay involved pipetting $0.2,0.4,0.6,0.8,1.0 \mathrm{ml}$ of garlic acid solution $(1.0 \mathrm{mg} / \mathrm{I})$ in triplicate in clean dried test tubes. The volumes were made up to $1.0 \mathrm{ml}$ with distilled water. To each of the test tube was added $1.5 \mathrm{ml}$ of $10 \%$ $(\mathrm{w} / \mathrm{v}) \mathrm{NaHCO}_{3}$ solution to give a total volume of $4.0 \mathrm{ml}$. The reaction mixtures were further incubated for additional one and half hours. The estimation of phenol in ethanolic extract of $S$. mombin involved pipetting $0.5 \mathrm{ml}$ each of $5 \mathrm{mg} / \mathrm{mI}$ ethanolic extract into clean dry test tubes in triplicate. The volumes were adjusted to $1.0 \mathrm{ml}$ with distilled water. To each of the tubes was added $1.5 \mathrm{ml}$ of Folin-Ciocalteu's phenol reagent (1:10). The reaction mixture was incubated at room temperature for 5 mimutes. To the reaction mixture was added $5 \mathrm{ml}$ of $10 \%(\mathrm{w} / \mathrm{v}) \mathrm{NaHCO}_{3}$ solution. The reaction mixture was incubated for one and half hour. The absorbance was read at $725 \mathrm{~nm}$ against the blank containing all reagents except the standard gallic acid. The absorbance at $725 \mathrm{~nm}$ was plotted against the concentration to produce the standard curve. The concentrations of the phenolies in the extract was extrapolated from standard curve and expressed as milligram tannic acid equivalent per $\mathrm{g}$ of extract (mg TAE/g extract) [16].

\section{Determination of proximate analysis of Cleistopholis patens (Benth)}

The proximate parameters (moisture, dry matter, ash, crude fats, proteins and fibers, nitrogen, carbohydrates and energy values) were determined using Association of Official Analytical Chemists Methods [14]

1. Determination of moisture content was done by drying samples in oven (WiseVen, WON-50, Korea) at $110^{\circ} \mathrm{C}$ until constant weight was attained [22].

2. Nitrogen estimation was carried out by the micro-Kjeldahl (BUCHI, KjelFlex K-360, Switzerland) method with some modification [23]. 
3. The crude proteins were subsequently calculated by multiplying the nitrogen content by a factor of 6.25 [23].

4. The energy value estimation was done by summing the multiplied values for crude protein, Crude fat and carbohydrate respectively at Water Factors $(4,9$ and 4$)$. Crude fats were determined by Soxhlet apparatus using $n$-hexane as a solvent.

5. The ash values were obtained by heating samples at $550{ }^{\circ} \mathrm{C}$ in a muffle furnace (Wise Therm, FHP-03, Korea) for $3 \mathrm{~h}$ [23].

6. The carbohydrate content was determined by subtracting the total crude protein, crude fiber, ash content and crude fat from the total dry matter [22].

7. Crude fiber was estimated by acid-base digestion with $1.25 \%$ $\mathrm{H}_{2} \mathrm{SO}_{4}(\mathrm{v} / \mathrm{v})$ and $1.25 \% \mathrm{NaOH}(\mathrm{w} / \mathrm{v})$ solutions [24].

\section{Elemental analysis of Cleistopholis patens (Benth)}

The major elements comprising calcium, sodium, potassium and trace elements (Fe and $\mathrm{Zn}$ ) were determined according to the standard method with slight modification [5,25]. The ground samples were sieved with a $2 \mathrm{~mm}$ rubber sieve and $2 \mathrm{~g}$ of each of the plant samples were subjected to dry ashing in porcelain crucible at $550^{\circ} \mathrm{C}$ in a muffle furnace. The resultant ash was dissolved in $5 \mathrm{ml}$ of $\mathrm{HNO}_{3} / \mathrm{H}_{2} \mathrm{O}_{2}(1: 1)$ and heated gently on hot plate until brown fumes disappeared. To the remaining material in each crucible, $5 \mathrm{ml}$ of deionized water was added and heated until a colourless solution was obtained. The mineral solution in each crucible was transferred into a $100 \mathrm{ml}$ volumetric flask by filtration through a Whatman filter paper and the volume was made to mark with deionized water. This solution was used for elemental analysis by atomic absorption spectrophotometer (AAS). Concentration of each element was calculated on percentage of dry matter.

\section{Results}

Table 1 showed the result results for the field Extract of Cleistopholis patens. The plant parts used are leaf and stem bark. The initial weight of the leaf is $300 \mathrm{~g}$, the volume of solvent used is $1,200 \mathrm{ml}$. Cleistopholis patens ethanol leaf extract is $8.2 \mathrm{~g}$ and for Aqueous extract is $7.2 \mathrm{~g}$. while the initial weight of stem bark is $300 \mathrm{~g}$, and volume of solvent used is $1,200 \mathrm{ml}$, Cleistopholis patens ethanol stem bark extract is $7.2 \mathrm{~g}$ and for Aqueous extract is $6.4 \mathrm{~g}$.

Table 2 shows the antimicrobial activities of Cleistopholis patens ethanol leaf extracts on selected clinical organisms. Four concentrations were used namely; $60,30,15$, and $7.5 \mathrm{mg} / \mathrm{ml}$ and two controls were used

\begin{tabular}{|c|c|c|c|c|}
\hline Plant part used & Initial weight & Volume of solvent & Ethanol & Aqueous \\
\hline Leaf & $300 \mathrm{~g}$ & $1,200 \mathrm{ml}$ & $8.2 \mathrm{~g}$ & $7.3 \mathrm{~g}$ \\
\hline stem Bark & $300 \mathrm{~g}$ & $1,200 \mathrm{ml}$ & $7.2 \mathrm{~g}$ & $6.4 \mathrm{~g}$ \\
\hline
\end{tabular}

Table 1: Result for the yield of each extracts. namely; ciprofloxacin and metronidazole. All clinical organisms show higher zones of inhibition at $60 \mathrm{mg} / \mathrm{ml}$ and lower zones of inhibition at $7.5 \mathrm{mg} / \mathrm{ml}$. control show 28.0 at $30 \mathrm{mg} / \mathrm{ml}$ zones of inhibtion on Klebsiella pneumonia, while Salmonella typhi and Aspargilius flavus shows lower or reduced Zone of inhibition of $19 \mathrm{~mm}$ at $30 \mathrm{mg} / \mathrm{ml}$ (Figure 1).

Table 3 shows the antimicrobial activities of Cleistopholis patens in aqueous leaf extract on selected clinical organisms. Four concentrations were used namely; $60,30,15,7.5 \mathrm{mg} / \mathrm{ml}$ and two controls were used namely; Ciprofloxacin and Metronidazole. All clinical organisms show higher zones of inhibition at $60 \mathrm{mg} / \mathrm{ml}$ and lower zones of inhibition at $7.5 \mathrm{mg} / \mathrm{ml}$. control shows $28.0 \mathrm{~mm}$ at $30 \mathrm{mg} / \mathrm{ml}$ on Klebsiella pneumonia while Salmonella typhi, Aspergillus flavus and Staphylococcus aureus shows lower or reduced zone of inhibition of $19 \mathrm{~mm}$ at $30 \mathrm{mg} / \mathrm{ml}$ (Figure 2).

Table 4 shows the antimicrobial activities of Cleistopholis patens ethanol stem bark extracts on selected clinical organisms. Four concentrations were used namely; $60,30,15,7.5 \mathrm{mg} / \mathrm{ml}$ and two controls were used namely; Ciprofloxacin and Metronidazole. All clinical organisms show higher zones of inhibition at $60 \mathrm{mg} / \mathrm{ml}$ and lower zones of inhibition at $7.5 \mathrm{mg} / \mathrm{ml}$. control shows $28.0 \mathrm{~mm}$ at 30 $\mathrm{mg} / \mathrm{ml}$ on Klebsiella pneumonia while Salmonella typhi, Aspergillus flavus and Staphylococcus aureus shows lower or reduced zone of inhibition of $19.0 \mathrm{~mm}$ at $30 \mathrm{mg} / \mathrm{ml}$ (Figure 3).

Table 5 shows the antimicrobial activities of Cleistopholis patens aqueous stem bark extracts on selected clinical organisms. Four concentrations were used namely; $60,30,15,7.5 \mathrm{mg} / \mathrm{ml}$ and two controls were used namely; Ciprofloxacin and Metronidazole. All clinical organisms show higher zones of inhibition at $60 \mathrm{mg} / \mathrm{ml}$ and lower zones of inhibition at $7.5 \mathrm{mg} / \mathrm{ml}$. control shows $28.0 \mathrm{~mm}$ at 30 $\mathrm{mg} / \mathrm{ml}$ on Klebsiella, Pneumonia while Salmonella typhi, Aspergillus flavus and Staphylococcus aureus shows lower or reduced zone of inhibition of $19 \mathrm{~mm}$ at $30 \mathrm{mg} / \mathrm{ml}$ (Figure 4)

Table 6 shows the qualitative analysis of the phytochemical screening of Cleistopholis patens. The qualitative analysis of the phytochemical screening of Cleistopholis patens bark extracts. Alkaloid and anthraquinone are negative while cardiac glycoside, steroid, phenol, tannins, saponin, and flavonoids are positive.

The qualitative analysis of the phytochemical screening of Cleistopholis patens Leaf extract. Alkaloid, steroid, and anthraquinone are negative while cardiac glycoside, phenol, tannins, and saponin are positive. Flavonoids are not detected.

Table 7 shows the quantitative analysis of minerals present in Cleistopholis patens of leaf and stem bark extracts. The quantitative analysis of minerals present in Cleistopholis patens of stem bark extracts. Nine minerals were used namely; Sodium $(\mathrm{Na})$, Potassium $(\mathrm{K})$, Calcium $(\mathrm{Ca})$, Magnesium $(\mathrm{Mg})$, Zinc ( $\mathrm{Zn})$, Iron (Fe), Lead (Pb),

\begin{tabular}{|c|c|c|c|c|c|c|}
\hline Conc $\mathrm{mg} / \mathrm{ml}$ & Escherichia coli & Salmonella typhi & $\begin{array}{l}\text { Candida } \\
\text { albicans }\end{array}$ & Klebsiella pneumonia & Aspergilus flavus & Staphylococcus aureus \\
\hline $60 \mathrm{mg} / \mathrm{ml}$ & 12.0 & 11.0 & 10.0 & 12.0 & 9.0 & 10.0 \\
\hline $30 \mathrm{mg} / \mathrm{ml}$ & 7.0 & 7.0 & 6.0 & 10.0 & 7.0 & 6.0 \\
\hline $15 \mathrm{mg} / \mathrm{ml}$ & 2.0 & 3.0 & 3.0 & 5.0 & 3.0 & 3.0 \\
\hline $7.5 \mathrm{mg} / \mathrm{ml}$ & 1.0 & 0.0 & 0.0 & 0.0 & 0.0 & 0.0 \\
\hline Ciprofloxacin $30 \mathrm{mg} / \mathrm{ml}$ & 20.0 & 19.0 & 20.0 & 28.0 & 19.0 & 20.0 \\
\hline Metronidazole $30 \mathrm{mg} / \mathrm{ml}$ & 20.0 & 21.0 & 22.0 & 20.0 & 20.0 & 19.0 \\
\hline
\end{tabular}

Table 2: Antimicrobial activities of Cleisthiopholis patens ethanolic leaf extracts on selected pathogenic isolates (inhibitory zone diameter-mm). 
Citation: Osuntokun OT (2018) Evaluation of Inhibitory Zone Diameter (IZD), Phytochemical Screening, Elemental Composition and Proximate Analysis of Crude Cleistopholis Patens (Benth) on Infectious Clinical Isolates. J Mol Biomark Diagn 9: 385. doi: 10.4172/2155-9929.1000385

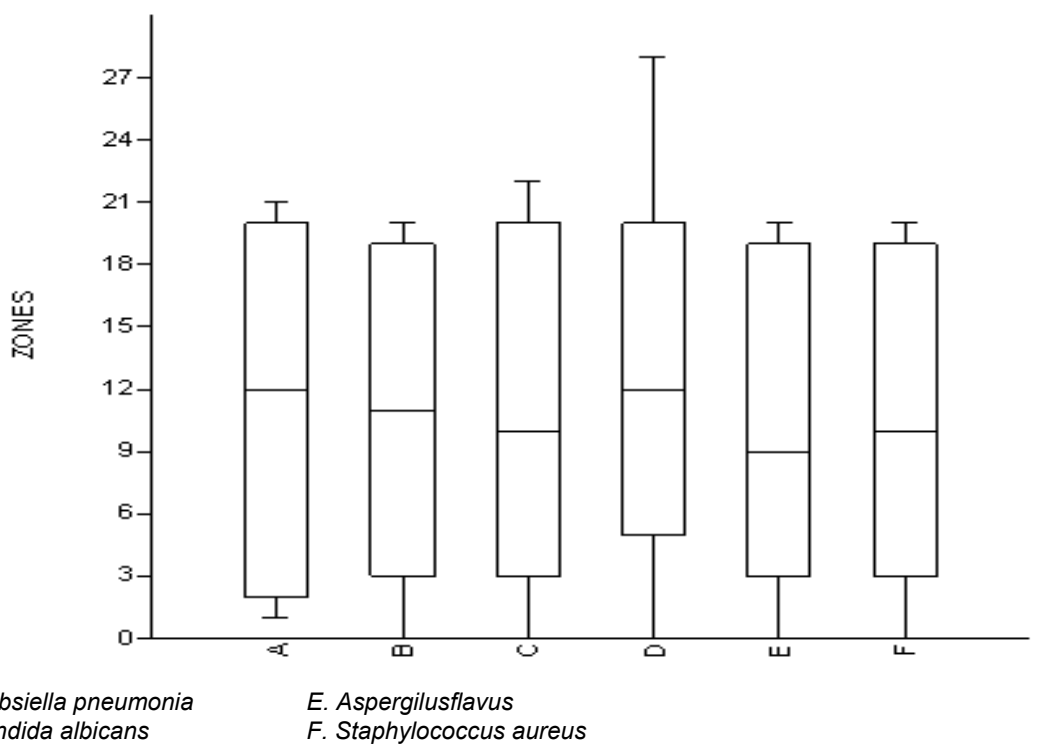
A. Escherichia coli
C. Klebsiella pneumonia
E. Aspergilusflavus
B. Salmonella typhi
D. Candida albicans
Ftaphylococcus aureus

Figure 1: Showing the antimicrobial activities of Cleisthiopholis patens ethanolic leaf extracts on selected pathogenic isolates.

\begin{tabular}{|c|c|c|c|c|c|c|}
\hline Conc $\mathrm{mg} / \mathrm{ml}$ & Escherichia coli & Salmonella typhi & $\begin{array}{l}\text { Candida } \\
\text { albicans }\end{array}$ & Klebsiella pneumonia & Aspergilus flavus & Staphylococcus aureus \\
\hline 60 & 10.0 & 13.0 & 12.0 & 9.0 & 8.0 & 12.0 \\
\hline 30 & 5.0 & 4.0 & 14.0 & 12.0 & 5.0 & 8.0 \\
\hline 15 & 1.0 & 1.0 & 2.0 & 2.0 & 2.0 & 1.0 \\
\hline 7.5 & 1.0 & 0.0 & 1.0 & 0.0 & 0.0 & 0.0 \\
\hline Ciprofloxacin 30 & 20.0 & 19.0 & 20.0 & 28.0 & 19.0 & 20.0 \\
\hline Metronidazole 30 & 20.0 & 20.0 & 22.0 & 20.0 & 20.0 & 19.0 \\
\hline
\end{tabular}

Table 3: Antimicrobial activities of Cleisthiopholis patens aqueous leaf extracts (inhibitory zone diameter-mm)

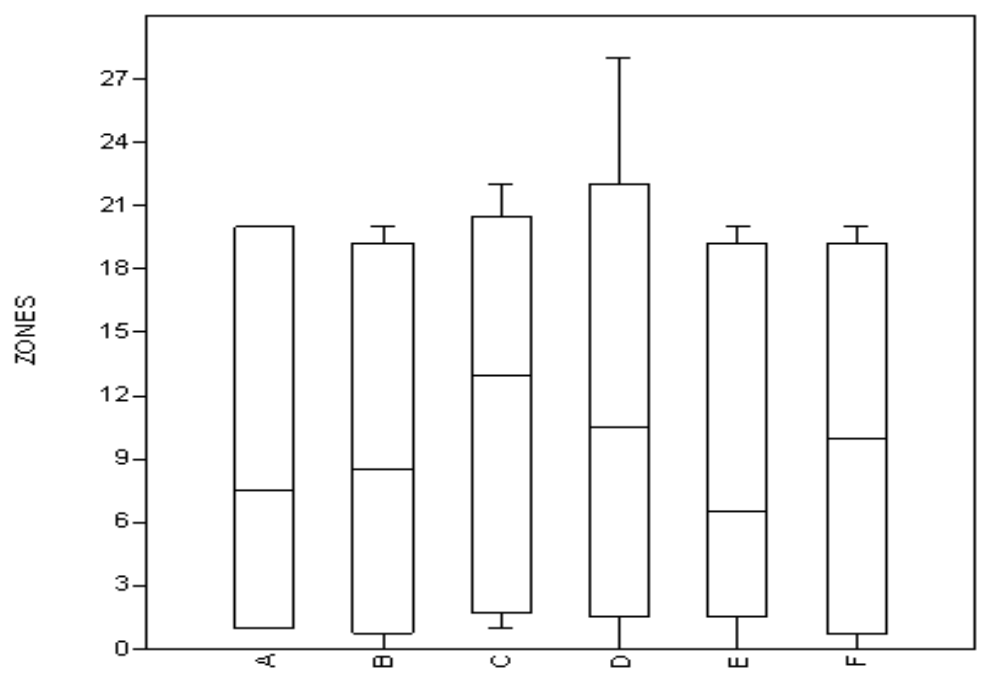
A. Escherichia coli
C. Klebsiella pneumonia
E. Aspergilusflavus
B. Salmonella typhi
D. Candida albicans
F. Staphylococcus aureus

Figure 2: Showing the antimicrobial activities of Cleisthiopholis patens ethanolic leaf extracts on selected pathogenic isolates. 
Citation: Osuntokun OT (2018) Evaluation of Inhibitory Zone Diameter (IZD), Phytochemical Screening, Elemental Composition and Proximate Analysis of Crude Cleistopholis Patens (Benth) on Infectious Clinical Isolates. J Mol Biomark Diagn 9: 385. doi: 10.4172/2155-9929.1000385

Page 6 of 9

\begin{tabular}{|c|c|c|c|c|c|c|}
\hline Conc $\mathrm{mg} / \mathrm{ml}$ & Escherichia coli & Salmonella typhi & $\begin{array}{l}\text { Candida } \\
\text { albicans }\end{array}$ & $\begin{array}{c}\text { Klebsiella } \\
\text { pneumonia }\end{array}$ & Aspergilus flavus & Staphylococcus aureus \\
\hline 60 & 9.0 & 10.0 & 10.0 & 11.0 & 9.0 & 10.0 \\
\hline 30 & 5.0 & 7.0 & 6.0 & 6.0 & 7.0 & 6.0 \\
\hline 15 & 2.0 & 3.0 & 3.0 & 3.0 & 3.0 & 3.0 \\
\hline 7.5 & 1.0 & 0.0 & 0.0 & 0.0 & 0.0 & 1.0 \\
\hline Ciprofloxacin 30 & 20.0 & 19.0 & 20.0 & 21.0 & 19.0 & 20.0 \\
\hline Metronidazole 30 & 20.0 & 21.0 & 22.0 & 22.0 & 18.0 & 19.0 \\
\hline
\end{tabular}

Table 4: Antimicrobial activities of Cleisthiopholis patens ethanolic stem bark extracts (inhibitory zone diameter-mm).

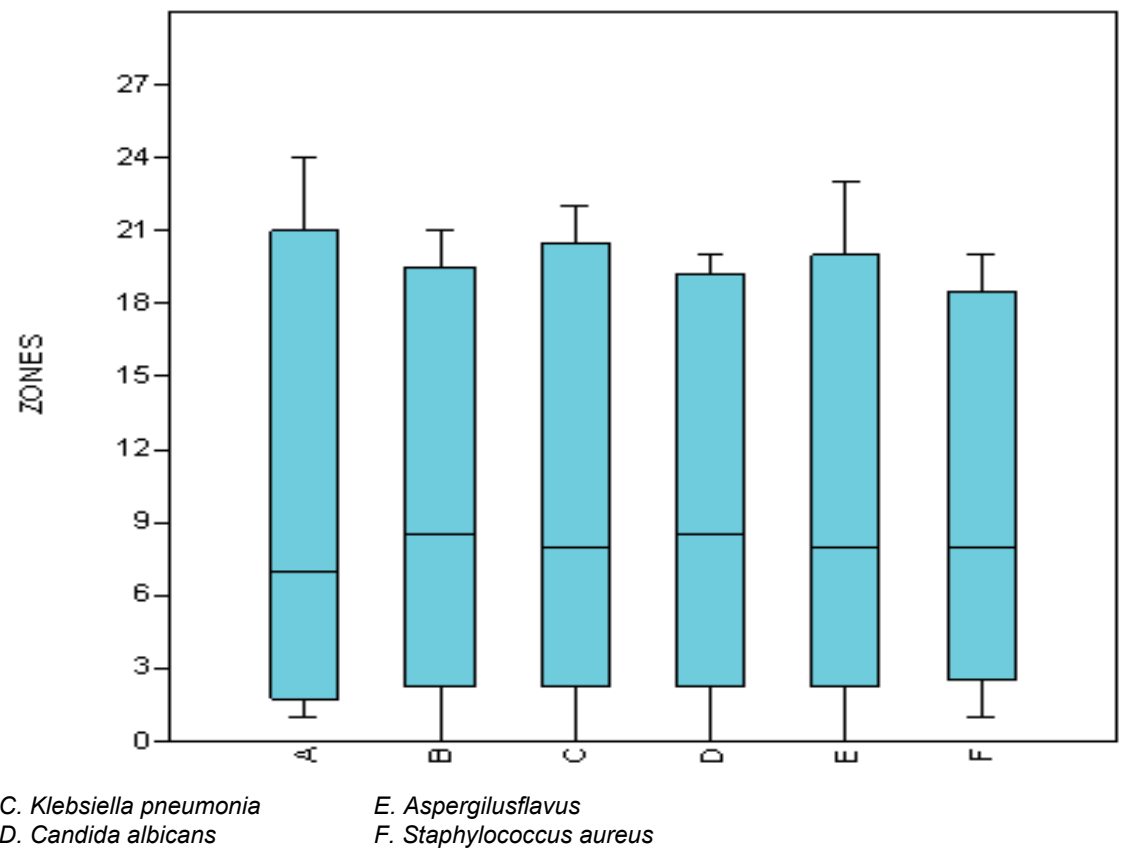

Figure 3: Antimicrobial activities of Cleisthiopholis patens ethanolic bark extracts.

\begin{tabular}{|c|c|c|c|c|c|c|}
\hline Conc $\mathrm{mg} / \mathrm{ml}$ & Escherichia coli & Salmonella typhi & Candida albicans & Klebsiella pneumonia & Aspergilus flavus & Staphylococcus aureus \\
\hline 60 & 10.0 & 13.0 & 10.0 & 9.0 & 7.0 & 11.0 \\
\hline 30 & 5.0 & 6.0 & 10.0 & 6.0 & 5.0 & 8.0 \\
\hline 15 & 4.0 & 2.0 & 2.0 & 4.0 & 2.0 & 2.0 \\
\hline 7.5 & 1.0 & 0.0 & 1.0 & 0.0 & 0.0 & 1.0 \\
\hline Ciprofloxacin 30 & 21.0 & 19.0 & 20.0 & 28.0 & 19.0 & 20.0 \\
\hline Metronidazole 30 & 23.0 & 20.0 & 22.0 & 21.0 & 20.0 & 19.0 \\
\hline
\end{tabular}

Table 5: Antimicrobial activities of Cleisthiopholis patens aqueous stem bark extracts (inhibitory zone diameter-mm).

\begin{tabular}{|c|c|c|c|c|c|c|c|c|}
\hline Sample & Alkaloid & $\begin{array}{l}\text { Cardiac } \\
\text { Glycoside }\end{array}$ & Steroid & $\begin{array}{l}\text { Anthraq- } \\
\text { uinone }\end{array}$ & Phenol & Tannins & Saponin & Flavonoids \\
\hline Cleisthiopholis patens Stem bark & - ve & + ve & + ve & - ve & + ve & + ve & + ve & $+\mathrm{ve}$ \\
\hline Cleisthiopholis patens Leaf & - ve & + ve & - ve & - ve & + ve & + ve & + ve & ND \\
\hline
\end{tabular}

Table 6: Qualitative analysis of the phytochemical screening of Cleistopholis patens

Copper $(\mathrm{Cu})$ and Manganese $(\mathrm{Mn})$. In Cleistopholis patens stem bark extract Zinc ( $\mathrm{Zn})$ has $28.0 \mathrm{mg} / \mathrm{g}$ which is the highest while copper has the lowest which is $0.03 \mathrm{mg} / \mathrm{g}$.

Table 8 shows the quantitative analysis of minerals present in Cleistopholis patens of leaf extracts. Nine minerals were used namely; Sodium (Na), Potassium (K), Calcium (Ca), Magnesium (Mg), Zinc
(Zn), Iron $(\mathrm{Fe})$, Lead $(\mathrm{Pb})$, Copper $(\mathrm{Cu})$ and Manganese $(\mathrm{Mn})$. In Cleistopholis patens leaf extract Calcium $(\mathrm{Ca})$ has $25.32 \mathrm{mg} / \mathrm{g}$ which is the highest while copper has the lowest which is $0.03 \mathrm{mg} / \mathrm{g}$. while Lead $(\mathrm{Pb})$ was not detected.

Table 8 shows the quantitative analysis of Anti-nutrients present in Cleistopholis patens stem bark and leaf extracts. Seven anti-nutrients 


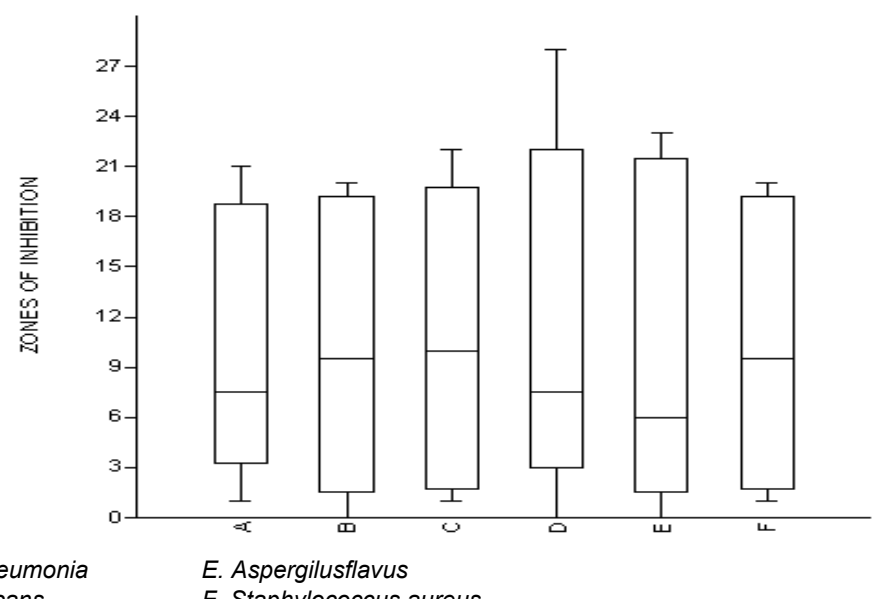
C. Klebsiella pneumonia
F. Staphylococcus aureus

Figure 4: Antimicrobial activities of Cleisthiopholis patens aqueous bark extracts.

\begin{tabular}{|c|c|c|c|c|c|c|c|c|c|}
\hline Plant sample used & $\mathrm{Na}$ & $\mathbf{K}$ & $\mathrm{Ca}$ & Mg & Zn & $\mathrm{Fe}$ & $\mathbf{P b}$ & $\mathrm{Cu}$ & Mn \\
\hline Cleisthiopholis patens Stem bark & 24.03 & 30.14 & 32.31 & 26.09 & 28.09 & 6.70 & ND & 0.03 & 6.30 \\
\hline Cleisthiopholis patens Leaf & 21.03 & 25.32 & 29.00 & 21.37 & 20.36 & 5.82 & ND & 0.01 & 5.31 \\
\hline
\end{tabular}

Note: ND = Not Detected

Table 7: Quantitative analyses of minerals present in plant Extract $(\mathrm{mg} / 100 \mathrm{~g})$ of Cleistopholis patens.

\begin{tabular}{|c|c|c|}
\hline Parameters & $\begin{array}{c}\text { Stem bark } \\
\text { Cleisthiopholis patens }\end{array}$ & $\begin{array}{c}\text { Leaf } \\
\text { Cleisthiopholis patens }\end{array}$ \\
\hline Tannin & 2.20 & 2.10 \\
\hline Phenol & 3.50 & 3.55 \\
\hline Phylate & 17.30 & 17.27 \\
\hline Oxalate & 3.69 & 3.70 \\
\hline Saponin & 13.89 & 14.01 \\
\hline Flavonoid & 8.53 & 8.55 \\
\hline Alkaloids & 1.23 & 1.25 \\
\hline
\end{tabular}

Table 8: Quantitative analyses of anti-nutrients present in plant extracts result in percentage (\%) of Cleistopholis patens.

\begin{tabular}{|c|c|c|c|c|c|c|}
\hline Plants & $\%$ Ash & $\%$ MC & \% CP & $\%$ Fat & $\%$ Fibre & \% CHO \\
\hline $\begin{array}{c}\text { Cleisthiopholis } \\
\text { patens Stem bark }\end{array}$ & 12.67 & 9.38 & 13.33 & 6.48 & 11.45 & 46.69 \\
\hline $\begin{array}{c}\text { Cleisthiopholis } \\
\text { patens leaf }\end{array}$ & 12.00 & 9.23 & 11.36 & 8.53 & 13.65 & 48.91 \\
\hline Note: MC = Moisture Content; CP = Crude Protein; CHO = Carbohydrate \\
\hline
\end{tabular}

Table 9: Quantitative analyses of proximate nutrient composition of plant extracts Cleistopholis patens.

were used namely; Tannin, Phenol, Phylate, Oxalate, Saponin, Flavonoid, and Alkaloids. In Cleistopholis patens stem bark extract, Philae, has the highest ant-nutrients which is $17.30 \%$ while Alkaloids has the lowest anti-nutrients which is $1.23 \%$. In Cleistopholis patens leaf extract, Phylate, has the highest ant-nutrients which is $17.27 \%$ while Alkaloids has the lowest anti-nutrients which is $1.25 \%$.

Table 9 shows the quantitative analysis of proximate Nutrient composition of Cleistopholis patens stem bark and leaf extracts. Ash, moisture content, crude protein, fat, fibre and carbohydrate were used. In Cleistopholis patens stem bark extract, carbohydrate has the highest percentage which is $46.69 \%$ and Fat has the lowest percentage which is $6.48 \%$. In Cleistopholis patens leaf extract, carbohydrate has the highest percentage which is $48.91 \%$ and Fat has the lowest percentage which is $8.53 \%$.

\section{Discussion}

The use of Cleistopholis patens in the treatment of diseases has been old as the diseases themselves [26]. Cleistopholis patens has being used for thousands of years for natural therapies, alternative medicine and pharmaceutical $[27,28]$. It has being further confirmed that the plant extract could be used for the treatment of various infections [13]. Since ancient times, plants have been used by several communities to treat a large number of diseases, including infections.

The result of this study showed that the Cleistopholis patens extracts contained antimicrobial activities [29]. Cleistopholis patens shows remarkable inhibitory effect against Klebsiella pneumonia of the ethanol leaf extract of Cleistopholis patens. Salmonella typhi and Aspergilius flavus shows lower or reduced Zone of inhibition. However, Klebsiella pneumonia have the highest level of inhibition against Cleistopholis patens while Salmonella typhi, Aspergillus flavus and Staphylococcus aureus shows lower or reduced zone of inhibition [9].

The result varies with different phytochemical presents in Cleistopholis patens. The qualitative analysis shows the presence of cardiac glycoside, steroid, phenol, tannins, saponin, and flavonoids. These metabolites have been shown to be responsible for various therapeutic activities of Cleistopholis patens [30].

The qualitative analysis of minerals present shows that the Cleistopholis patens has varying degree of minerals which includes Sodium (Na), Potassium (K), Calcium (Ca), Magnesium (Mg), Zinc $(\mathrm{Zn})$, Iron $(\mathrm{Fe})$, Lead $(\mathrm{Pb})$, Copper $(\mathrm{Cu})$ and Manganese $(\mathrm{Mn})$. There is higher amount Zinc $(\mathrm{Zn})$ in Cleistopholis patens leaf extract, while there is high Calcium (Ca) in Cleistopholis patens tem bark extract [31].

The quantitative analysis of Cleistopholis patens present shows that the plants parts have varying degree of anti-nutrient such as tannin, phenol, phylate, oxalate, saponin, flavonoid, and alkaloids. Qureshi et al. [6] reported that stem bark and leaves showed distinct antimicrobial activity against pathogenic organism i.e. Salmonella typhimurium and 
Escherichia coli strains. The phytochemical test of the second plant parts, the leaf extracts of Cleistopholis patens Benth also revealed alkaloid, steroid, and anthraquinone are negative while cardiac glycoside, phenol, tannins, and saponin are positive. Flavonoids are not detected. The absence of major metabolites in leaf extracts of Cleistopholis patens might be the reason for their negligible antimicrobial activities against the test microorganisms.

Flavonoids in Cleistopholis patens acts as a "biological response modifiers" such as anti-allergic, anti-inflammatory, ant-microbial [30], and anti-cancer activities shown from in vitro studies [31]. According to Okwu [31], flavonoids are especially known for their anti-fungal effects against wide array of micro-organisms, the activities are attributed to their abilities to complex with extracellular and soluble proteins with microbial cell wall. Tannins have been found to form irreversible complexes with proline proteins resulting in inhibition of cell protein synthesis. Tannins are potent antioxidants and also used for treating diarrhea and dysentery. Alkaloids, the largest group of chemicals, produced by plants have many biological activities. Alkaloids (pure and synthetic) isolates are used as basic medicinal agents for their analgesic, antispasmodic, bactericidal effects $[32,33]$ and antifungal effects [5]. More so, saponins have been found to intercalate DNA of microorganism as mechanism of their antimicrobial activity [34] and thus exhibit antifungal activity.

On the analysis of proximate Nutrient composition there is high level of carbohydrate for the stem bark and leaf extract. However, there is low level of fats in both leaf and stem bark extract. Adonu et al. [4] reported that Cleistopholis patens showed the presence of carbohydrates, fats and oil. Phytochemical like proteins was not detected. The study indicates that Cleistopholis patens is useful in the treatment of cardiovascular disorders, stomach-ache, diarrhoea, tuberculosis, bronchitis fever, trypanosomiasis and rheumatic arthritis, menstrual irregularities, headache, hepatitis, malaria and measles [25].

\section{Conclusion}

The study has revealed the presences of anti-microbial properties of Cleistopholis patens. The study shows that the Cleistopholis patens plant is effective against Escherichia coli, Salmonella typhi, Candida albicans, Klebsiella pneumonia, Aspergilus flavus, and Staphylococcus aureus. Thus, it can be used for the treatment of a large number of diseases and several infections. Therefore the use of medicinal plants should be approved and used worldwide in the treatment of diseases.

\section{References}

1. Aliyu R, Adebayo AH, Gatsing D, Garba IH (2007) The effects of ethanolic leaf extract of Commiphora Africana (Burseraceae) on rat liver and kidney functions. J Pharmacol Toxicol 2: 373-379.

2. Ojewole JA, Adewunmi CO (2004) Anti-inflammatory and hypoglycaemic effects of Tetrapleura tetraptera (Taub) (fabaceae) fruit aqueous extract in rats. J Ethnopharmacol 95: 177-182.

3. Okigbo RN, Mmeka EC (2006) An appraisal of phytomedicine in Africa. KMITL Science Journal (Thailand) 6: 83-93

4. Adonu CC, Okechukwu PC, Esimone CO, Emmanuel C, Abubakar BAWA et al. (2013) Phytochemical analyses of the menthanol, hot water and n-hexane extracts of the aerial parts of Cassytha filiformis (Linn) and leaves of Cleistopholis patens (Benth). Res J Pharma Biol Chem Sci 4: 1143-1149.

5. Liu S, Oguntimein B, Hufford CD, Clark AM (1990). 3-Methoxysampangine, a novel antifungal copyrine alkaloid from Cleistopholis patens. Antimicrob Agents Chemother 34: 529-533.

6. Qureshi R, Bhatti GR (2009) Folklore uses of Amaranthaceae family from Nara desert, Pakistan. Pak J Bot 41: 1565-1572.
7. Addae-Kyereme J, Croft SL, Kendrick H, Wright CW (2001) Antiplasmodial activities of some Ghanaian plants traditionally used for fever/malaria treatment and some alkaloids isolated from Pleiocarpa mutica in vivo antimalarial activity of pleiocarpine. J Ethnopharmacol 76: 99-103.

8. Vats M, Singh H, Sardana S (2011) Phytochemical screening and antimicrobial activity of roots of Murayya koenyii (Linn) Spreng. (RUtaceae). Braz J Microbiol 42: 1569-1573.

9. Osuntokun OT, Olajubu FA (2014) Antibacterial and phytochemical properties of some Nigerian medicinal plant on Salmonella typhi and Salmonella paratyph isolated from infected human stool in Owo local Government. J Scientific Res Reports 4: 441-449.

10. Temitope $\mathrm{OO}$ (2015) Bioactivity and phytochemical screening of Nigerian medicinal plants growing in Ondo and Ekiti State against bacterial isolates from pediatrics hospital. J Adv Medical Pharmaceu Sci 4: 1-14.

11. Temitope OO, Ayodele A (2014) Antimicrobial, phytochemical and proximate analysis of four Nigerian medicinal plants on some clinical microorganisms. Curr Res Microbiol Biotechnol 2: 457-461.

12. Astal ZY, Ashour AE, Kerrit AA (2005) Antimicrobial activity of some medicinal plant extracts in Palestine. Pak J Med Sci 21: 187-193.

13. Osuntokun OT, Julianah JU, Thonda OA (2017) Bioprospective screening of antibacterial and phytochemical activity of Caesalpinia pulcherrima (Pride of Barbados) on selected clinical isolate. J Bioequiv Bioavailab 1: 1-11.

14. Trease GE, Evans MC (1983) Textbook of pharmacognosy, (12th edn) London: Tindall, UJ. pp. 343-383.

15. Sofowora A (1982) Medicinal Plants and Traditional medicine in Africa, (1st edn) New York: John Wiley and Sons Ltd, USA. pp. 168-171.

16. Edeoga HO, Okwu DE, Mbaebie BO (2005) Phytochemical constiuents of some Nigerian medicinal plants. Afr J Biotechnol 4: 685-688.

17. Doughari JH, Sunday D (2009) Antibacterial activity of Phyllanthus muellerianus. Pharma Biol 46: 400-405.

18. Kubmarawa D, Ajoku GA, Enwerem NM, Okorie DA (2007) Preliminary phytochemical and antimicrobial screening of 50 medicinal plants from Nigeria. Afr J Biotechnol 6: 1690-1696.

19. Guevarra BQ (2005) A guidebook to plant screening: phytochemical and biological. Manila, Philippines: UST Publishing House.

20. Sun Q, Mayeda A, Hampson RK, Krainer AR, Rottman FR (1999) General splicing factor ASF/SF2 promotes alternative splicing by binding to an exonic splicing enhancer. Genes Dev 7: 2598-2608.

21. Singleton VL, Orthofer R, Lamuela-Raventos RM (1999) Analysis of total phenols and other oxidation substrates and antioxidants by means of FolinCiocalteu reagent. Methods Enzymol 299: 152-178.

22. Horwitz W (2003) Official methods of analysis of AOAC international (17th edn) USA: Association of Official Analytical Communities.

23. Hussain J, Rehman N, Al-Harrasi A, Ali L, Ullah R, et al. (2011) Nutritiona prospects and mineral compositions of selected vegetables from Dhoda SharifKohat. J Med Plants Res 5: 6509-6514.

24. Al-Harrasi A, Al-Rawahi A, Hussain J, Rehman N, Ali L, et al. (2012) Proximate analysis of the resins and leaves of Boswellia sacra. J Med Plants Res 6: 30983104.

25. Wongsrichanalai C, Pickard AL, Wernsdorfer WH, Meshnick SR (2002) Epidemiology of drug-resistant malaria. Lancet Infect Dis 2: 209-218.

26. Azu NC, Onyeagba RA (2007) Antimicrobial properties of extracts of Allium cepa (Onions) and Zingiber officinale (Ginger) on Escherichia coli, Salmonella typhi, and Bacillus subtilis. The Internet J Trop Med 3: 1-7.

27. Jones FA (1996) Herbs-useful plants, Their role in history and Today. Euro $J$ Gastroenterol Hepatol 8: 1227-1231.

28. Martindale W (1996) Martindale: The Extra Pharmacopoeia, (31st edn), London: Royal Pharmaceutical Society of Great Britain, UK. pp. 21-25.

29. Lai LS, Chou ST, Chao WW (2001) Studies on the antioxidative activities of hsian-tsao (Mesona procumbens hemls) leaf gum. J Agric Food Chem 49: 963968.

30. Cushnie TP, Lamb AJ (2005) Antimicrobial activity of flavonoids. Int J Antimicrob Agents 26: 343-335. 
Citation: Osuntokun OT (2018) Evaluation of Inhibitory Zone Diameter (IZD), Phytochemical Screening, Elemental Composition and Proximate Analysis of Crude Cleistopholis Patens (Benth) on Infectious Clinical Isolates. J Mol Biomark Diagn 9: 385. doi: 10.4172/2155-9929.1000385

Page 9 of 9

31. Okwu DE (2003) The potentials of Ocimum gratissimum, Penrgularia extensa and Tetrapleura tetraptera as spice and flavouring agents. Niger Agric $\mathrm{J} 34$ : 143-148.

32. Stary F, Storchova H (1991) A mutual guide to medicinal herbs and plants, Tiger Books International, UK. pp. 44.
33. Talalay $P$, Talalay $P(2001)$ The importance of using scientific principles in the development of medicinal agents from plants. Academic Med 76: 238-247.

34. Jennings BR, Ridler PJ (1983) Interaction of chromosomal stains with DNA. An Electrofluorescence Study. Biophys Struct Mech 10: 71-79. 